\title{
The place of forestry in agriculture
}

\section{ANDREW POTTINGER 'Anerley', Tinui, Masterton}

\section{Abstract}

Many New Zealand pastoral farmers have experienced severe financial hardship due to lowerthan-adequate product prices and adverse climatic conditions in recent years. It is perhaps now appropriate to look at alternative land use for a proportion of their farm. Wood is a product which the world is desperately short of, and New Zealand can grow wood better than virtually anywhere else in the world. When we look at world demand for wood, both now and in the near future, we see that plantings are not keeping up with expected demands. The world would need an area 6 times that of New Zealand (i.e. 160 million ha) to satisfy the demand. At present, we only harvest $1.6 \%$ of the world's total harvest. In New Zealand the trend is in the right direction, with production predicted to reach 25 million cubic metres by 2015 (2.5 times present production). This will require $9.4 \%$ of the land area of New Zealand, but will produce $\$ 16$ billion, more than wool, meat and dairy together. Agroforestry gives farmers the opportunity to spread their risk beyond traditional agricultural products, and also participate in this growing industry of forestry. The question should not be whether trees are planted on some of our own farm land, but who will do it. Farmers have been slow to convert, but economics will prevail.

K eywords: agroforesty, economics, hill country, marginal hill country

\section{Introduction}

Over the past 30 years, New Zealand farmers have seen -a-steady decline in the real value of their major agricultural products. With all the major fluctuations there have been, the net trend has always been down. For example, in 1950 , the price of milkfat was $\$ 11.83$ in today's dollars, and the comparison for Iamb and wool is worse. All these trends are despite the subsidies received by sheepfarmers over the 1970s and despite the fact that the dairy industry is working hard to add value to its products by further processing.

However, there is one product that the world is desperately short of, that New Zealand can grow better than virtually anyone else, and that product is wood.

\section{W orld wood demand}

World population is increasing at 3 people per second and, with an average per capita annual wood consumption of 0.7 cubic metres per second, the average wood demand is increasing by 2 cubic metres every second. This equates to 7000 cubic metres per hour, 173000 cubic metres every day and 64 million cubic metres every year. To meet this demand we would need the equivalent of 3 million ha of fast-growing radiata pine every year.

If we were to satisfy the world's wood needs from only plantations, then we should already have planted 160 million ha of radiata or equivalent yielding species. (This is an area equivalent to six times New Zealand.) In fact, current world plantation forestry comprises less than 100 million ha.

\section{Forestry in $\mathrm{New}$ Zealand today}

Forestry earnings have increased $25 \%$ in 2 years from $\$ 1.4$ billion to $\$ 1.7$ billion to end June 1992 (Figure 1). At the present rate of increase of planting, New Zealand would have 2.5 million ha by the year 2020. This will earn around $\$ 16$ billion, but still only be $1.5 \%$ of the world's area needed to sustain predicted demands.

Figure 1 Value of principal exports for year ended June 1992

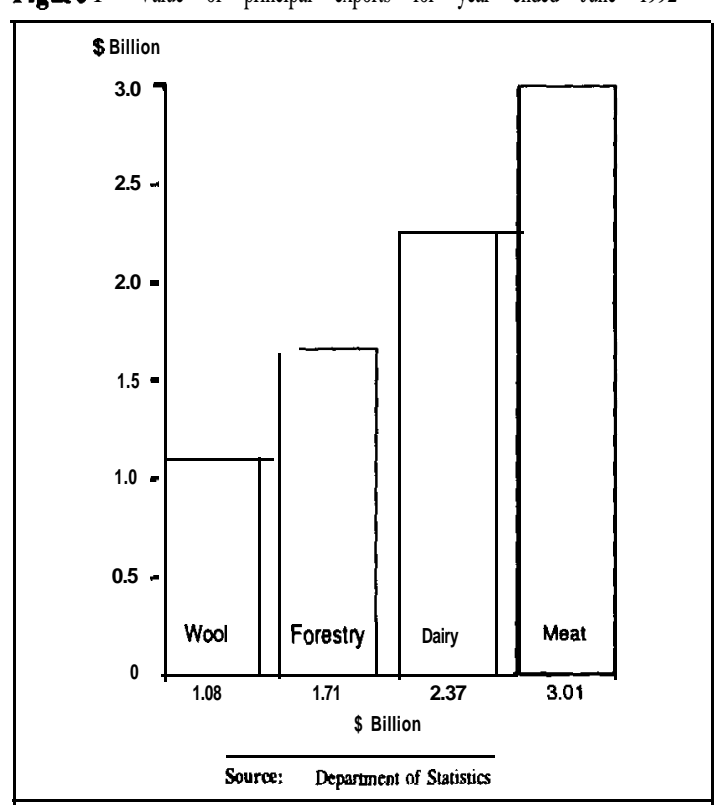




\section{How does all this fit into agriculture in New Zealand?}

\author{
N.Z. Area \\ 26.6 million ha \\ Area in forestry 1.17 million ha $=4.4 \%$ of total area, \\ producing 10 million tonnes of \\ wood.
}

With the current rate of planting, this will increase to 2.5 million ha, still only using $9.4 \%$ of the total area, which could be producing $\$ 16$ billion dollars, more than wool, dairy and meat put together. This extra land (1.5 million ha) should come from pastoral farming, and the trees should be established either as a crop on their own or as agroforestry.

\section{Why trees have been traditionally planted on farms}

1. Erosion control.

2. Shelter.

3. Production forest - limited resources.

\section{Agroforestry}

Agroforestry gives farmers the opportunity to spread their risk beyond traditional agricultural products, and at the same time participate in the forestry sector, for which the demand and price for product is steadily increasing.

Forest Research Institute (FRI) studies have shown that large areas of hill country in Manawatu, Hawkes Bay and the Wairarapa would be more profitable under an agroforestry regime than its present pastoral farming with sheep and beef. Hill country farmers must reassess their land use practices and consider planting more trees.

The question should not be whether trees should be planted on this land, but when and who will do it. Farmers have traditionally been slow to convert, but eventually economics will prevail and the marginal farm land will be converted. Trees have traditionally been thought of as providing shelter or erosion control, not as a crop on their own, Seventy-seven percent of sheep and beef farms have no productive trees on them, and those that did had planted only 2 ha on average (Source: Meat and Wool Boards Economic Service survey), is despite information indicating the deteriorating profitability in sheep and beef farming, compared with logs (Figure 2).

\section{Consequences of adopting agroforestry}

\section{Effect on livestock numbers}

At establishment stage, there will be a decrease in stock numbers, but this could be minimised if the least productive areas were planted first, so long as access was not compromised. In certain cases, as we have seen on highly erodible land, once grazing is resumed at year 3, the microclimate effect on better pasture can increase carrying capacity of livestock. The trees have stabilised the soil, allowing pasture to establish where there was no pasture prior to planting. Also wind erosion had been minimised.

Depending on the density of the tree crop, the LSU carried will decrease to almost nil at year 20. From studies done by FRI on a 245 ha farm in the eastern Bay of Plenty, a final crop of 225 stems per ha was best for log production, but this meant grazing disappeared sooner (year 15). Between year 3 and 15, very little effect should be seen on most of our marginal hill country:

\section{Effect on labour}

Looking at 225 stems per ha, on the FRI model farm of 83 ha, 20 days per year were required on average over the $25 / 30$ year period of the production cycle. In most existing farm situations, labour can be utilised to reduce the costs.

\section{Effect on cashflow}

There is a negative effect on the cashflow prior to felling starting. The amount of this will be determined

Figure 2 Long-term trends in real prices for sheep and beef products, and export $\log s$

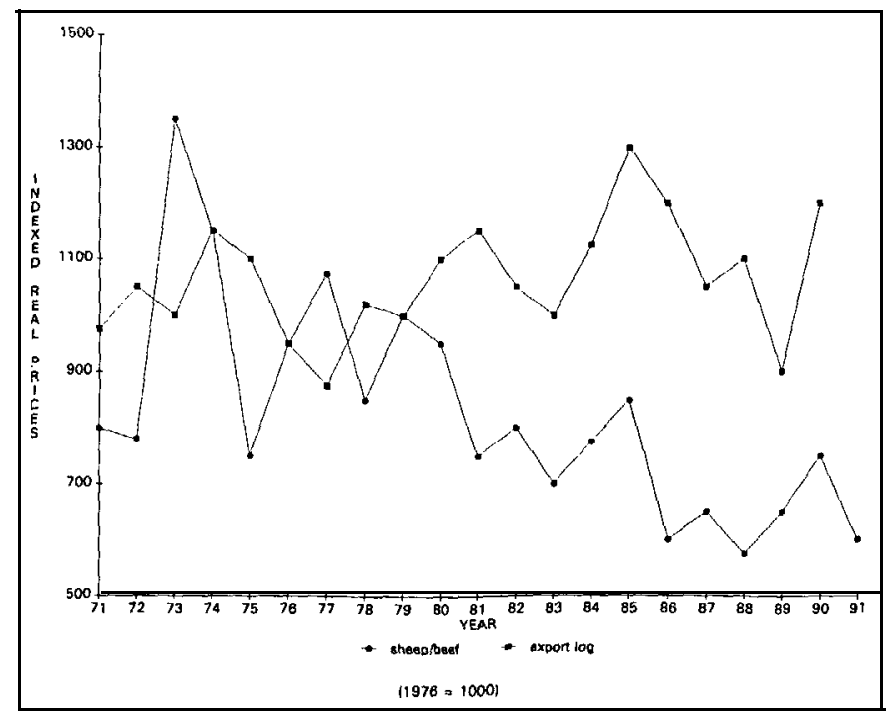


by factors such as:

(a) previous carrying capacity of land planted

(b) whether contract or existing labour is used

(c) growth rate of trees, affecting grazing available (Figure 3).

This assumes an ongoing planting programme. Once felling starts, it can be continuous and the deficits in the cashflow no longer exist. A static area is also assumed. To put this in dollar terms (once again using the FR data), the farm surplus increases by $\mathbf{1 3 5 \%}$, from $\$ 56000$ with no forestry, to $\$ 132000$ with agroforestry, using contract labour and $33 \%$ of total farm in 'agroforestry.

\section{Effect on profitability}

Studies done by FRI looked at various agroforestry options, as compared with farming (without trees) in terms of net present values. Fixed costs, including land, are the same for all options; therefore the analysis was done on marginal costs and revenues. Because trees are a lump sum crop, i.e., all the return comes at the end, we have to use a pre-tax discount rate to compare with farming, which has an annual income. At a discount rate of $8 \%$ using a wide range of farming gross margins, agroforestry is more profitable than farming, at a gross margin of less than $\$ 60$ per SU for farming. An alternative is to increase the livestock carrying capacity of the hill country. At a gross margin of $\$ 28.70$ per SU for livestock farming, carrying capacity would have to increase from $8 \mathrm{SU} /$ ha to 16 SU/ha to make agroforestry at $225 \mathrm{stems} / \mathrm{ha}$ less profitable than farming. While this increase may be physically possible, the cost of inputs of fertiliser, fencing, improved pasture species and labour would make the operation uneconomic and unsustainable apart from the risk of increased livestock pressure, especially cattle, on the marginal hill country we are looking at.

m Clearly trees are an economic and environmentally appropriate crop for this land.

\section{Own farm gross margin}

Agroforestry - 250 stems per ha yielding $630 \mathrm{~m}^{3}$ at year 28

Average net price to farmer $=\$ 45 \mathrm{~m}^{3}=$

$$
\$ 28,350 / \text { ha }
$$

therefore per year $\$ 28350$ divided 28 yrs $=$

$$
\$ 1012.50 / \mathrm{ha} / \mathrm{yr}
$$

Assume farm running $11 \mathrm{su} / \mathrm{ha}$ therefore $\$ 1012$ divided $11 \mathrm{su}=\$ 92 / \mathbf{s u} / \mathbf{y r}$ for $28 \mathrm{yrs}$ Sheep and Beef $\boldsymbol{\tau}$ current situation

$70 \%$ sheep $30 \%$ cattle $=\$ 32.50 / \mathrm{su} / \mathrm{yr}$ per ha $(\$ 32.50 \times 11)=\$ 357.50 / \mathrm{ha} / \mathrm{yr}$

Note: No account has been taken for grazing from year 3 to year 15/20, which would offset the pre-tax discount rate I spoke of earlier under profitability.

\section{Planting area}

How much land would be required to give you $25 \%$ of your gross farm income in forestry?

Assume my own situation:

1150 ha $70 \%$ sheep $30 \%$ cattle

Gross income: $\$ 350,000$ (10,000 SU @\$35/SU)

We want $25 \%$ of gross income coming from trees:

$$
25 \% \text { of } \$ 350,000=\$ 87,500
$$

$3.09 \mathrm{ha} / \mathrm{yr} @ \$ 28,350 / \mathrm{ha}=\$ 87,500$

On a 28-year rotation, assuming replanting as trees are felled, 87 ha would be needed $=7.56 \%$ of total farm area producing $25 \%$ of gross farm income, and with costs removed alot more than $25 \%$ of net farm income.

\section{Conclusion}

At present, trees can earn more for farmers and for the national economy than many agricultural products.

Projections indicate this advantage will increase as a result of both wood becoming more valuable and agricultural products less valuable. As a consequence, trees can compete strongly for land use, and the invasion 
of wood crops into pasture is inevitable. It is not a matter of whether it will happen, but how soon farmers make it happen, and I believe economics will prevail, and farmers will change a proportion of their land area into trees.

\section{Recommendations}

For farming on hill country to remain viable above the boom and bust cycle we have had over the past decades, I believe it is realistic and more important to aim at $10 \%$ of the farm's area in a production crop of trees. Whether this is agroforestry or straight forestry is up to the individual, but economics would point to agroforestry for the advantages already mentioned. The class of land planted would depend on the pressure required to maintain livestock numbers; if possible some of the better land should be planted first, but if not, be aware of access on more marginal land. If $10 \%$ is achieved, this would give a minimum of $25 \%$ of gross income coming from trees, and the dips and troughs in other farm income could be levelled out by increasing or decreasing this amount on an annual basis. Trees do not have to be harvested at a finite time, unlike livestock, wool or dairy products. Delaying harvesting simply adds to the eventual crop.

The important point is to start planting next winter!

\section{Postscript}

In the last 30 mimutes, 1500 ha of forest have been harvested, and the world population has increased by 5400 people. To satisfy just their wood needs, we should have planted the equivalent of 175 hectares of radiata pine!

\section{REFERENCES}

Cumberland, Garth 1992, Land use conflicts, 1991 Cumberland Farm Visit 1992.

Knowles, Leith 1991, Rotorua Trees are a valuable crop on their own, 1992. What's New in Forest Research, 1991.

Ward, Tom, Wellington Regional Council Personal communications and providing Ministry of Forest Quarterly reports, 30 September, 1992. 